Article Type: Research Paper

\title{
Efforts to Improve Employee Creativity Through Transformational Leadership
}

\author{
Majang Palupi
}

\begin{abstract}
This study aimed to examine the effect of transformational leadership on employee creativity. In this study, transformational leadership was seen from four dimensions: inspirational motivation, idealized influence, intellectual stimulation, and individual consideration. This study's sampling technique was the purposive sampling technique by selecting Master program students who have worked. This study had distributed a total of 117 questionnaires, and the number of usable questionnaires was 100 employees. This study applied multiple regression to process the data. The results showed that the four transformational leadership dimensions, consisting of inspirational motivation, idealized influence, intellectual stimulation, and individual consideration, influenced employee creativity.
\end{abstract}

\section{AFFILIATION:}

${ }^{1}$ Department Management, Faculty of Business and Economics, Universitas Islam Indonesia, Yogyakarta, Indonesia

*CORRESPONDENCE:

majang_palupi@uii.ac.id

THIS ARTICLE IS AVAILABLE IN:

http://journal.umy.ac.id/index.php/mb

DOI: $10.18196 / \mathrm{mb} .112100$

\section{CITATION:}

Palupi, M. (2020). Efforts to Improve Employee Creativity Through Transformational Leadership. Jurnal Manajemen Bisnis, 11(2), 224-232.

\section{ARTICLE HISTORY}

Received:

23 July 2020

Reviewed:

14 August 2020

Revised:

29 August 2020

Accepted:

31 August 2020
Keywords: Employee creativity; Idealized influence; Individual consideration; Inspirational motivation; Intellectual stimulation; Transformational leadership.

\section{Introduction}

Today's disruptive era has made the external environment becoming more challe nging to predict. External changes which are very fast have forced companies to adapt internally quickly. Therefore, companies must have high adaptability in adjusting to a radically changing business environment. These highly competitive changes require employee creativity (Wang, Tsai, \& Tsai , 2014). From the perspective of the resource-based view, the human resources' role is becoming central and most expected by companies. Employee creativity is a capital that must be developed because it can give birth to product, service, and process innovations for business sustainability. Employee creativity can also help an organization or company last a long time and exist in the market, and have strong competitiveness to compete in the market. The reason is that creativity can make creative contributions that are more efficient and responsive to opportunities, help companies to survive, can adapt to changes, grow, and survive in market competition globally (Beheshtifar \& Zare, 2013).

Creativity refers to a person's freedom of expression in generating new ideas to achieve company goals (Argia \& Ismail, 2014). Someone with high creativity can create something new and is characterized by originality when expressing an artistic nature. 
Palupi

Efforts to Improve Employee Creativity Through Transformational Leadership

Employees with creativity are expected to provide creative ideas to improve their performance and company performance. By developing creativity and sharing with other employees, the company promotes participation in innovating and ultimately impacts companies that can compete globally. Therefore, companies need to increase their employees' creativity to contribute to creating products or offering services that are useful for companies to compete globally.

The study of leaders' attitudes and behaviors in the workplace is still interesting. Researchers see that aspects of leaders' attitudes and behavior significantly influence many outcomes within the company (Yukl, 2013; Pangesti, Tjahjono, \& Maryati, 2013). Work creativity is one of the increasingly important outcomes in organizational studies so that organizations strive to build work creativity. The essential things in increasing work engagement include behavior that shows support and motivation. Leaders' attitudes and behavior are an organization's driving force (Tjahjono \& Palupi, 2015). Transformational leadership is a complete leadership concept, containing four dimensions: inspirational motivation, idealized influence, intellectual stimulation, and individual consideration (Bass \& Avolio, 1994).

\section{Literature Review and Hypotheses Development}

Shin, Taylor, and Seo (2012) define employee creativity as new and useful ideas about products, services, processes, and procedures produced by employees. Creative ideas owned by employees are expected to be applied to their work, developed, and can be disseminated to other employees in the company. Employee creativity can be interpreted as an idea or a new idea generation (Shin et al., 2012). It will be useful and is recognized as a significant contributor to organizational innovation and competitive advantage in an uncertain or dynamic environment (Chang, Takeuchi, Jia, \& Cai, 2014).

Employee creativity is ideas' development related to products, services, practices, or new procedures and has potential use for an organization (Amabile, 1996; Amabile, Schatzel, Moneta, \& Kramer, 2004). Furthermore, creativity has become a significant theme in the world of industry and work. Most superiors or managers level in a company are aware of the fact that to exist in market competition, and a company needs employees to be actively involved in tasks and work. Creativity can also be interpreted as using employee's various skills, abilities, knowledge, views, and experience to produce a new idea or idea in making decisions, solving a problem, and completing a task efficiently (Suifan \& AlJanini, 2017).

Amabile (2012) stated that in comparative theory, creativity is influenced by three individual components: domain-relevant skills, creativity-relevant processes, and task motivation. Skills related to the domain include knowledge, expertise, technical skills, intelligence, and talent in a particular area where problem-solvers work, such as product designers. Processes that are relevant to creativity contain cognitive styles and personality characteristics that are conducive to freedom, risk-taking, and taking new perspectives on problems, as well as work style and disciplinary skills in generating ideas. 
Palupi

Efforts to Improve Employee Creativity Through Transformational Leadership

This cognitive process includes the ability to use broad and flexible categories to synthesize information and release from perception and performance scripts. The personality process includes self-discipline and tolerance for ambiguity.

On the other side, intrinsic task motivation is enthusiasm. It is motivation to perform a task or solve a problem, which can be caused by the interesting, engaging, challenging, or personally satisfying (rather than doing it from extrinsic motivation arising from a contract) for rewards, supervision, competition, evaluation, or the requirements to do things a certain way. The main principle of the comparative theory is the intrinsic motivation's principle of creativity, namely, the most creative people are when they feel motivated, mainly because of the interests, enjoyment, satisfaction, and challenges of the work itself (not by extrinsic motivators). Therefore, as research has shown, prominent extrinsic motivators can weaken intrinsic motivation; their presence or absence in the social environment is essential.

\section{Transformasional Leadership}

A leader figure is a person who gives meaning and influence to the organization so that the leader has the potential to have a central role (Tjahjono, 2004). Transformative ability is the ability needed to develop innovative, empowering subordinates into a changing way of thinking and understanding of organizational goals to feel involved and responsible for completing work. The transformational leadership concept was based on Burns's (1978) idea, which was furthermore complemented by Bass (1985, 1996 in Yukl, 2013).

\section{Individual and Organizational Characteristics \\ - Life experience \\ - Organizational culture}

- Trait
The impact on

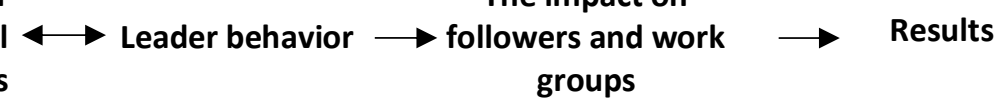

- Inspirational motivation

- Ideal influence

- Individual consideration

- Intellectual stimulation
- Increased intrinsic motivation, achievement orientation, and goal pursuit

- Trust in leaders

- Unity with group members

- Increased selfconfidence, selfeffectiveness, and intrinsic interest in achieving goals

- Increasing examples of transformational leadership
- Personal commitment to the leader and vision

- Self-sacrificing behavior

- Organizational commitment

- Fulfillment of meaning in work and satisfaction

- Improvement of individual, group, and organizational performance

Figure 1 Transformational Leadership Model Source: Kinicki and Fugate, 2018 
Palupi

Efforts to Improve Employee Creativity Through Transformational Leadership

Transformational leadership can be defined as leadership that increases awareness of the collective interests among organizational members and helps them achieve their collective goals (Bass \& Avolio, 1993). With transformational leadership, followers can feel trust, admiration, loyalty, and respect for leaders. Followers are motivated to do more than was initially expected of them. According to Bass et al. in Tjahjono, Prasetyo, and Palupi (2018), transformational leaders play the role of making changes and providing motivational injections.

Transformational leaders change their followers by creating changes in their goals, values, needs, beliefs, and aspirations. Transformational leaders complete this transformation by comparing it with the followers' self-concept (values and personal). Figure 1 presents a model of how these transformational leaders achieve the transformation process. Bass (1985, 1988 in Yukl, 2013) characterizes leadership consisting of the following four characteristics.

Inspirational motivation characteristics refer to leadership behaviors, such as giving meaning to the followers' work and articulating an interesting or inspiring vision for the team or organization. In this context, inspirational motivation is a leader who communicates high expectations to followers, provides inspiration with motivation for something to be done, and runs all parts of the organization's vision. The leader uses emotional appeal to influence his followers in achieving perceptions more than their abilities. Thus, it encourages employees to be more focused on achieving the vision with the creativity they have.

Idealized influence can be defined as an influence on ideal values and refers to transformational leader models' behavior and their extraordinary personal qualities. In this context, the ideal influence is the leaders with strong role models to followers, who identify themselves as leaders and want to be better at behavior, morals, and ethics, and can be expected to do something right. The leaders are highly respected by followers and are very trusted. They provide vision and mission to followers.

Intellectual stimulation means that transformational leaders encourage followers to challenge existing assumptions, reframe problems, and approach them in new ways. Bass and Avolio (1994) also assumed that subordinates feel that leaders encourage them to rethink how they work, find new ways of carrying out tasks and feel new ways of perceiving their tasks. Intellectual stimulation is the leader's actions in influencing subordinates to be creative and innovative and providing challenges in demonstrating the ability to learn. This leader type encourages subordinates to try new ways and develop innovative ways of solving a problem. This action will encourage subordinates to think of a way out in solving problems carefully. In a highly competitive environment like today, a more creative workforce is needed to provide high-quality services. Transformational leadership is considered effective in increasing employee creativity.

Individual consideration relates to the behavior of coaching and mentoring transformational leaders, which brings individual differences between followers. Bass and Avolio (1994) concluded that subordinates feel cared for and explicitly treated by their 


\section{Palupi}

Efforts to Improve Employee Creativity Through Transformational Leadership

leaders in the individual considerations' characteristics. The leader treats each of his subordinates as a person with the skills, needs, and desires. Leaders create a sense of ability to subordinates that they can do a good job and be creative to achieve goals.

Each of the four components describes the essential characteristics of the "transformation" process. When the managers are strong role models, supporters, innovators, and mentors, they utilize "four dimensions" to help turn their partners into more productive and successful individuals. Transformational leadership becomes a process that causes a change in individuals and social systems in organizations. Based on the theory and logic at the level, the hypothesis is arranged as follows:

\section{$\boldsymbol{H}_{1}$ : Inspirational motivation has a positive effect on employee creativity \\ $\boldsymbol{H}_{2} \quad$ : Idealized influence has a positive effect on employee creativity \\ $\mathrm{H}_{3} \quad$ : Intellectual stimulation has a positive effect on employee creativity \\ $\mathrm{H}_{4} \quad$ : Individualized consideration has a positive effect on employee creativity}

\section{Research Model}

Dimensions of

Transformational Leadership

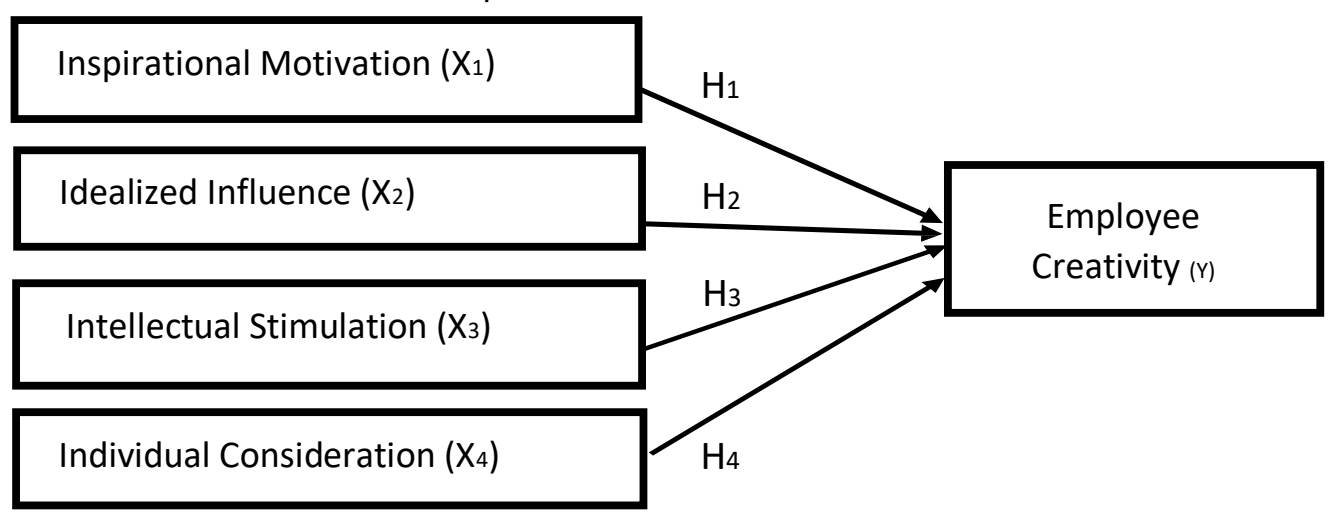

Figure 2 Research Model

\section{Research Methods}

\section{Research Type}

Quantitative research methods used in the research were surveys. Primary data were data collected for research from the actual place where an event occurred. Primary data is a 


\section{Palupi}

Efforts to Improve Employee Creativity Through Transformational Leadership

type of data obtained directly from the original source (Tjahjono, 2015). Primary data were specifically obtained to answer research questions.

\section{Sample and Population}

The population in this study were educated employees, so the proxy that depicted educated and creative employees took master's education as many as 117 employees. The sampling technique was used based on the ease of obtaining data, namely, the convenience sampling technique.

\section{Definition of Operational Variabel}

\section{Transformational Leadership}

Transformational leadership style is the subordinates' assessment toward the direct leader on the leaders' ability to support and motivate subordinates to think creatively and understand differences between individuals to improve work performance and develop subordinates' potential. The four transformational leadership dimensions are inspirational motivation, idealizing influence, intellectual stimulation, and individual consideration (Bass \& Avolio, 1994).

\section{Creativity}

Employee creativity attempts to produce an idea carried out by an employee related to new products, services, practices, and procedures and potentially has benefits for an organization and the company (Zhou \& George, 2001).

Testing the instrument's validity was seen from the aspect of the face and content validity, then empirical testing was performed, showing all valid items as measuring variables. Reliability testing also showed that all items of reliable questions were with Cronbach alpha above 0.7 . Thus, the whole item was consistent in measuring the variables.

\section{Results and Discussion}

Respondent data showed that $56 \%$ were single, and $100 \%$ were millennials (the current age was under 40 years old). Based on gender, it consisted of 39 women and 61 men.

Table 1 Descriptive data related to the answer of respondents

\begin{tabular}{clc}
\hline \multicolumn{1}{c}{ Variable } & Mean \\
\hline No & Inspirational motivation & 4,22 \\
2. & Idealized influence & 4,12 \\
3. & Intellectual stimulation & 4,17 \\
4. & Individual consideration & 4,19 \\
5. & Creativity & 3,92 \\
\hline
\end{tabular}

In general, the four dimensions of transformational leadership, including inspirational motivation, idealized influence, intellectual stimulation, and individual consideration, 
Palupi

Efforts to Improve Employee Creativity Through Transformational Leadership

were perceived by high respondents. At the same time, the self-report creativity assessment was also highly perceived.

\section{Hypothesis Test}

Before testing the hypothesis, the determination coefficient was calculated to see the model test's suitability. The test model can be seen from the adjusted $R$ square, which showed the results of 0.670 . These results indicated that the variables' variation of transformational justice dimensions could explain the variation of the creativity variable of 0.670 . Meanwhile, the rest was explained by other variables' variations, not in the research model. Meanwhile, hypothesis testing can be seen in Table 2.

$$
\text { Regression equation } Y=0,230 X 1+0,192 \times 2+0,333 \times 3+0,267 X 4
$$

Hypothesis testing showed the following:

Inspirational motivation had a positive effect on creativity. Based on the regression test results, the regression coefficient value was positive $(0.230)$ and sig value $0.012<\alpha(0.05)$. It signified that inspirational motivation had a positive effect on employee creativity. Thus, it also identified that transformational leadership could inspire or motivate employees to show their work creativity.

Table 2 Multiple Regression Analysis: Variable Y (Creativity)

\begin{tabular}{clcc}
\hline No & \multicolumn{1}{c}{ Variabel } & Beta & Sig \\
\hline 1. & Inspirational motivation & 0,230 & 0.010 \\
2. & Idealized influence & 0,192 & 0,039 \\
3. & Intellectual stimulation & 0,333 & 0,000 \\
4. & Individual consideration & 0,267 & 0,023 \\
\hline
\end{tabular}

The idealized influence had a positive effect on creativity. The regression test results showed that the regression coefficient value was positive (0.192) and sig value $0.039<\alpha$ (0.05). It indicated that idealized influence had a positive effect on employee performance. It also identified that transformational leadership could provide vision and positive examples of subordinates' attitudes and behavior. Leaders could also pay attention to their subordinates and instill a sense of pride, so employees were encouraged to develop creativity.

Individual consideration had a positive effect on creativity. Based on the regression test results, it was shown that the regression coefficient value was positive $(0.267)$ and a sig value of $0.023>\alpha(0.05)$. It denoted that transformational leadership paid attention to subordinates personally, respected individual differences, and could give advice and rewards to build creativity and performance.

Intellectual stimulation had a positive effect on creativity. The results of the regression test revealed that the regression coefficient value was positive (0.333) and sig value of $0,000<\alpha(0.05)$. It implied that transformational leadership sought to create a conducive climate to the ideas' development for those involved in the process of problem formulation and finding solutions. Differences of opinion are seen as common. It would 
Palupi

Efforts to Improve Employee Creativity Through Transformational Leadership

make subordinate's self-efficacy stronger so that they would be able to do and succeed in carrying out various challenging tasks.

The four dimensions of transformational leadership would be a very good synergy and influence followers to feel more confident and respectful for their leaders. They would be motivated to do better tasks and undoubtedly affect creativity. Transformational leadership gives confidence through a personal approach to better understand his subordinates further and in other forms, to better the organization.

\section{Conclusion}

Based on the research results and analysis, it could be concluded that transformational leadership positively affected employee creativity. Specifically, the effect of each transformational leadership dimension on employee creativity is as follows: Inspirational motivation had a positive effect on employee creativity. The idealized influence had a positive effect on employee creativity. Interactive stimulation had a positive effect on employee creativity. Individual consideration had a positive effect on employee creativity.

\section{Suggestion and Limitation}

One limitation of this study is the limited number of samples. Convenience sampling techniques have consequences for the low ability to generalize. Besides, the creativity variables' measurement had the potential for attributive bias because employees assessed themselves on the dependent variable and assessed the leadership of others.

Future research is essential to select a larger sample size with more rigorous and representative sampling techniques for the population. Besides, future research is essential to design the questionnaire to minimize the potential for bias carefully.

\section{References}

Amabile, T. M. (1996). Creativity in Context: Update to the Social Psychology of Creativity. Boulder, CO: Westview Press.

Amabile, T. M., Schatzel, E. A., Moneta, G. B., \& Kramer, S. J. (2004). Leader behaviors and the work environment for creativity: Perceived leader support. Leadership Quarterly, 15(1), 5-32. https://doi.org/10.1016/j.leaqua.2003.12.003

Amabile, T.M. (2013) Componential Theory of Creativity. In: Kessler, E.H., Ed., Encyclopedia of Management Theory, Sage Publications, London, 134-139. http://dx.doi.org/10.4135/9781452276090.n42

Argia, H. A. A, \& Ismail, A. (2014). The Influence of Transformational Leadership on the Level of TQM Implementation in the Higher Education Sector. Canadian Center of Science and Education.3(1). https://doi.org/10.5539/hes.v3n1p136

Bass, B. M., \& Avolio, B. J. (1993). Transformational leadership and organizational structure. International Journal of Public Administration Quarterly, 17, 112-121.

Bass, B. M., \& Avolio, B.J. (Eds). (1994). Improving organizational effectiveness through 


\section{Palupi}

Efforts to Improve Employee Creativity Through Transformational Leadership

transformational leadership. Sage Publications, Inc.

Bass, B.M., Avolio, B.J., Jung, D.I \& Berson, Y. (2003). Predicting Unit Performance by assessing transformational and transactional leadership. Journal of Applied Psychology, 88(2), 207-218. https:// doi.org/10.1037/0021-9010.88.2.207

Beheshtifar, M., \& Zare, E. (2013). Employee Creativity: A compulsory Factor in Organizations. Interdisciplinary journal of contemporary research in business, 5(2), 242-247. Retrieved from https://journal-archieves33.webs.com/242-247.pdf

Burns, J.M. (1978). Leadership. New York: Harper and Row.

Chang, S., Takeuchi, R., Jia, L., \& Cai, Y. (2014). Do High-Commitment Work Systems Affect Creativity? A Multilevel Combinational Approach to Employee Creativity.Journal of Applied Psychology, 99(4), 665- 680. https://doi.org/10.1037/a0035679

Kinicki, A. \& Fugate, M. (2018). Organizational Behavior. McGraw Hill Education International Edition.

Pangesti, G. R., Tjahjono, H.K., \& Maryati, T. (2013). The influences of transformational leadership, motivator factor, and hygiene factor toward job satisfaction of balai besar latihan ketransmigrasian Yogyakarta's employee. Jurnal Bisnis: Teori dan Implementasi, 4(1): 31-44. Retrieved from https://journal.umy.ac.id/index.php/bti/article/view/2432

Shin, J., Taylor, M. S., \& Seo, M. G. (2012). Resources for change: The relationships of organizational inducements and psychological resilience to employees' attitudes and behaviors toward organizational change. Academy of Management Journal, 55(3), 727-748. https://doi.org/10.5465/amj.2010.0325

Suifan, T. \& Al-Janini, M. (2017). The Relationship between Transformational Leadership and Employeess' Creativity in Jor\&ian Banking Sector. International Review of Management and Marketing, 7(2), 284- 292. Retrieved from http://www.econjournals.com/index.php/irmm/article/view/4284

Tjahjono, H.K. \& Palupi, M. (2015). Kepemimpinan intrapersonal dan implikasi organisasional. Jurnal Bisnis: Teori dan Implementasi, 6(2), 207-215. Retrieved from https://journal.umy.ac.id/index.php/bti/article/view/2526

Tjahjono, H.K. (2004). Budaya Organisasional dan Balanced Scorecard: Dimensi Teori dan Praktik. UPFE UMY

Tjahjono, H.K. (2015). Metode Penelitian Bisnis. VSM MM UMY.

Tjahjono, H.K., Prasetyo, F. \& Palupi, M. (2018). Kepemimpinan transformasional pada organizational citizenship behavior dan komitmen afektif. Jurnal Manajemen dan Pemasaran Jasa, 11(2): 217-232. http://dx.doi.org/10.25105/jmpj.v11i2.2771

Wang, C. J., Tsai, H. T., \& Tsai, M. T. (2014). Linkin Transformational Leadership and Employee Creativity in The Hospitality Industry: The Influences of Creative Role Identity, Efikasi diri kreatif, and Job Complexity. Tourism Management, 40(C), 79-89.

Yukl, G. (2013). Leadership in Organization, 8th Editions. Pearson.

Zhou, J. \& George, J.M. (2001). When Job Dissatisfaction Leads to Creativity: Encouraging The Expression of Voice. Academy of Management Journal, 44 (4), 682-696. https://doi.org/10.5465/3069410 